\title{
The Pragmatics of Greetings Reflected in the Textbooks \\ for Teaching English as a Foreign Language in Indonesia
}

\author{
Iin Inawati \\ STKIP Muhammadiyah Pringsewu Lampung \\ inawati.upi@gmail.com
}

\begin{abstract}
This article reports on the finding of a study which aims to analyze the pragmatic content of nine school textbooks intended for use in Indonesian secondary schools. Specifically, the article examines how greetings are linguistically presented in the textbooks and whether adequate metapragmatic information is provided to facilitate the learning of the greetings. The analysis shows that less various types of greetings are presented in the textbook and meta-pragmatic information is limited. It is suggested for teacher and textbooks writers to reconsider the types of instructional materials that can most effectively prepare learners for communication in a wider and more diverse world.
\end{abstract}

Keyword: textbooks, greetings, meta-pragmatic

\section{Introduction}

Textbooks play important role in language learning environment but unfortunately, textbooks may misrepresent the target language culture and its social rules of speaking (LoCastro, 2008). It is in line with Nguyen (2011) who states that textbooks do not always constitute an accurate and adequate source of pragmatic information and argued for the need to provide realistic pragmatic models that are necessarly accompanied by adequate explanation of rules of use in order to facilitate leraners' development of pragmatic competence in the target language.

Some studies have been conducted regarding the pragmatic content in textbooks. The studies found that conversation in the textbooks evaluated are not pragmatically appropriate, efficacious and functional (Koosha \& Dastjerdi, 2011; Soozandehfar \& Sahrgard, 2011; Kohandani, et al., 2014 and Ekin, 2013), quantity and quality of pragmatic information in the books is inadequate as a source to gain pragmatic competence (Wichien and Aksornjarung, 2011; Aksoyalp \& Toprak, 2014; Alemi, et al., 2013; Diepenbroek, \& Derwing, 2013), course books do not provide their learners with different strategies that requests, refusals or complaint require (Delen and Tavil, 2010), there is a dearth of pragmatic information contained in the textbooks and the variety of pragmatic information is limited and most of the

The Pragmatics of Greetings Reflected in the Textbooks for Teaching English 1 as a Foreign Language in Indonesia 
meta-pragmatic explanations are simple (Peiying (2007), there are pragmalinguistic transfer in textbook made by non-native speaker (Vaezi, et. al., 2014). Nevertheless, there is one study which find that sociopragmatic representation of a speech act (thanking) in the course books is appropriate and used by native speaker (Pablos-Ortega, 2010).

Even though the evaluation of textbook regarding of speech acts has been conducted by some scholars from some other countries, such kind of research is under research in Indonesia. So, it is needed to conduct a research that evaluate the speech acts content in the textbooks used in Indonesia especially the text books used at secondary level. This study investigate specifically on 1) the linguistic presentation of greeting in textbook and 2) and meta-pragmatic information accompanying these presentation.

\section{Literature Review}

\subsection{English greetings and the linguistic presentation}

Greeting is important in developing and maintaining social bonds in all age groups. Ebsworth et al. (1996) states that their research shows that greetings are complex, involving a wide range of behaviors and a sensitivity to many situational and psychosocial variables. Greetings in American English are made up of a range of linguistic and non-verbal choices which may include a simple wave or smile, a single utterance or a lengthy speech act set which can involve complex interactional rules and take place over a series of conversational turns. English greetings have different pattern and role compared to greetings in other culture, such as: Persian (Salmani-Nodousan, 2007), Vietnam (Hang, 2009), Ghanaian (Sekyi-Baidoo\& Koranteng, 2008) and China (Li, 2009).

In addition, Ebsworth, et al. (1996) study about greetings also classify eight types of greeting by native speakers. 1). Greetings on the run. It is greeting among intimates and acquaintances. Two people see each other and exchange brief phatic statements or questions which do not necessarily require responses. 2) Speedy greeting that begins and ends abruptly. The information is exchanged. 3) The chat. This greeting includes a short discussion on a topic or two before either leave-taking or the real purpose of the communication is introduced. 4) The long greeting involves reestablishing bonds between two people after a period of separation. 5) The intimate greeting occurs between people who know each other well and speak frequently. The speakers may know each other so well that they may leave a great deal implied or unsaid. 6) All-business greeting. It is sometimes characterized with a very short preliminary greeting or, sometimes, no greeting at all. 7) The introductory greeting involves greeting between two people who are meeting for the first time. The primary function of the interactions is to allow the parties to find a connection (mutual friends, mutual experiences) or a topic of mutual interest. 8) The regreeting, involves acknowledging someone you have greeted earlier or see repeatedly during the day. It can involve a nonverbal gesture (a nod or a wave) or a few quick words which refer to a shared topic. The classification of

The Pragmatics of Greetings Reflected in the Textbooks for Teaching English 2 as a Foreign Language in Indonesia 
greetings by Ebsworth et al. is used to analyze the greetings in the study.

\subsection{Meta-pragmatic information in textbooks}

Every conversation is very contextual and it is necessary for textbooks to give appropriate contextual information before a dialogue is presented in textbooks. Contextual means 1) information about relationship between the speakers, for example, how close they feel to one another, how likely can one impose what one wants on the other. 2) Description of the contextual variables that might help to judge the degree of imposition of the speech act involved (Brown and Levinson, 1987). In some other cases, the relationship between speakers could be inferred from their roles (e.g. customer and salesperson, father and son, patient and doctor).

Meta-pragmatic information is about when, where, and to whom it is appropriate to perform a particular speech act and what expression would or would not be appropriate in a particular context of culture and situation (Nguyen, 2011). Providing contextual clues and meta-pragmatic information on politeness or norms of appropriateness is essential for learners to understand differential socio-cultural constraints on the use of speech acts in different cultures. As Brown and Levinson (1987) have pointed out, a consideration of such contextual clues as the degree of social distance between speakers (D), their relative power status (P), and the degree of imposition of the speech act involved (R) helps one in deciding how to go about achieving politeness in performing this speech act. Further, as shown in previous cross-cultural and intercultural pragmatics research, these $D, P$, and $\mathrm{R}$ factors might exert differential effects in different cultures.

It is argued that accepting meta-pragmatic information in the classroom can help students to develop pragmatic competence, such as constructive criticism (Nguyen, at al., 2012), conventional expression (Bardovi-harlig and Vellega, 2012) hearsay evidential marker (Narita, 2012), advise giving (Eisenclas, 2011), request (Halenko and Jones, 2011; Takimoto, 2008), and thanking (Ghobadi \& Fahim, 2009). It is the duty of the teacher to provide meta-pragmatic information in the classroom, but unfortunately the teacher are over reliance on textbook on teaching (Chow and MokCheung, 2004; Cox, 1999). Because of that reasons, meta-pragmatic information is important in accompanying conversation in the textbooks.

\section{Methodology}

\subsection{Subjects}

Subjects of this study were nine school textbooks, six books published by government and three books were published by private publisher (see Appendix). Five textbooks were claimed that have already gotten legalization from Badan Nasional Standardisasi Pendidikan and declared that they have fulfilled requirements to be used as materials in English language teaching in classrooms. While the other books did not clarify legalization case.

\subsection{Design}

The Pragmatics of Greetings Reflected in the Textbooks for Teaching English 3 as a Foreign Language in Indonesia 
This study employed content analysis technique in which enables researcher to study written contents, such as textbooks (Fraenkel and Wallen, 2007). In this study, the school textbooks for EFL learners had been analyzed in terms of pragmatic contents.

\subsection{Data Analysis}

In content analysis, the researcher followed some stages. The stages started from determining objectives (choosing textbooks), define terms (in this study: greetings), specify the unit of analysis (dialogue and list of useful expression), develop rationale, develop a sampling plan, formulate coding categories then analyze the data based on the theme and research questions (Fraenkel and Wallen, 2007). After analysis was carried out the conclusion could be drawn.

\section{FINDINGS AND DISCUSSIONS}

\subsection{The Linguistics Presentation of Greeting in Textbooks}

An analysis of the linguistic presentations of greetings in nine textbooks tended to indicate that from 59 dialogues, 28 dialogues (48\%) were not clear or could not be classified into the categories proposed by Ebsworth (1996).

The Example 1 can be seen as an example.

\section{Example 1}

A female student : Good morning.

A policeman : Good morning.

(WERB/d.40/p.3/nc)

In such short conversation without pragmatic information, it seemed difficult to reach the purpose of greeting which is to provide means for opening conversations appropriately and for establishing and maintaining social relationships (Goffman, 1971 in Li, 2009).

Besides, the analysis also found that from 59 dialogues, 18 dialogues (30\%) dialogues presented in the textbooks were included in the introductory greeting (Ebsworth, 1996), as seen in the Example 2.

\section{Example 2}

Heru is a new neighbor.

Ary : Hello. I'm Ary.

Heru : Hello. I'm Heru.

Ary : You are the new neighbor, right?

Heru : Yes, I am. I just moved from Padang.

Ary : Well, nice to meet you, Heru.

Heru : Nice to meet you, too. (BISMP/d.5/p.3/g.7)

The dialog above seemed to indicate that the dialogue was between two people who did not know each other and they produced introduction conversation. So, it could be classified into The introductory greeting that involved greeting between two people who were meeting for the first time. It 
can be said that this kind of greeting is one in which the primary function of the interactions is to allow the parties to find a connection (mutual friends, mutual experiences) or a topic of mutual interest (Ebsworth, 1996). It seemed to suggest that the textbooks provide less various types of greetings and this condition brings disadvantages to the books users. It is supported by Delen \& Tavil (2010) who found that course books do not provide their learners with different strategies that the speech acts require.

\subsection{Meta-pragmatic Information Accompanying the Presentations}

Meta-pragmatic information is about when, where, and to whom it is appropriate to perform a particular speech act and what expression would or would not be appropriate in a particular context of culture and situation (Nguyen, 2011). When looking at the contextual presentations of the different greeting, the findings seemed to suggest an inadequate treatment. The textbooks showed two typical ways of presenting greetings, i.e. using dialogues and using list of useful expressions.

The total dialogues from five books are 59 and 20 dialogues (34\%) were presented with some information of context and 13 (22\%) dialogues presented without context and meta-pragmatic information at all. In addition, $26(44 \%)$ dialogues were presented by using pictures. Example 3 shows the contextual and meta-pragmatic information needed in the dialog.

\section{Example 3}

It is 8 a.m. Mr. Akbar is doing something in the office. A few minutes later, his manager arrives and greets him. He says:

Manager : Good morning, Mr. Akbar. How are you?

Mr. Akbar : Fine, thanks.

And how re you?

Manager : Very well. Thank you. (PYE/d.31/p. 2/g.2)

The data seemed to suggest that there is explicit information about when, where and to whom the expression are uttered (Nguyen, 2011). However, this meta-pragmatic information is still inadequate because information about distance (D), power (P) and degree of imposition of the speech act involved $(R)$ are important to be presented in a conversation (Brown \& Levinson, 1987). The meta-pragmatic (when, where, and to whom) information accompanying dialog presented in textbooks was available only in 5 from 59 dialogues analyzed in this study. The other meta-pragmatic information on the other conversations were not sufficient. Some of them gave information only about situation, or only place when the dialogue was conducted as seen in the following data.

Heru is a new neighbor (BISMP/d.5); Anto is Ucok's best friend (BISMP/d.8); In the dining room (CTL/d.22); In the shool canteen (CTL/d. 25); Today is the commemoration of national Education Day. 
Every province in Indonesia sends their representatives to attend outstanding students gathering in Jakarta (DEC/d.58), Cipto waiting for Andi and Yani, his new colleague at the airport (DEC/d.69)

The data showed that the students got disadvantages in getting inadequate information of the dialogues. On the other hand, some dialogues and list of useful expression in the textbooks did not provide explicit information about the relationship between the speakers or when, where, and to whom it was appropriate to perform a particular speech act (Nguyen, 2011) as seen in Example 4.

\section{Example 4}

Activity 8: Listen carefully to the following dialogue and study it. Then practice it with your friend.

Mirna: Hi, Toni, nice to meet you again after long holiday.

Toni : Hello. Mirna, nice to meet you too.

(DEC/d.57/p.5/g.4)

Besides, in adequate information also could be found in the list of useful expression as seen in the table 1 where there was no information about when, where, and to whom it was appropriate to perform the greetings.

Table 1. List of useful expression with limited meta-pragmatic information. Study the following expression of greetings, introducing, meeting and parting.

\begin{tabular}{|l|l|}
\hline Greetings & Responses \\
\hline Good morning. & Good morning. \\
\hline Good afternoon. & Good afternoon. \\
\hline Good evening. & Good evening. \\
\hline How nice to see you. & Yes, it's been so nice. \\
\hline Hello. & Hello. \\
\hline How are you? & Fine, thanks. \\
\hline How do you do? & How do you do? \\
\hline How're you doing? & Not bad. \\
\hline Hi! & Hi! \\
\hline
\end{tabular}

(DEC, p. 9).

The data above do not show how close they feel to one another, or how likely can one impose what one wants on the other. Nor was there a description of the contextual variables that might help to judge the degree of imposition of the speech acts involved (Brown and Levinson, 1987). It seemed to suggest that the meta-pragmatic information in textbooks was limited, simple and inadequate as a source to gain pragmatic competence. It is supported by Peiying's study (2007) which found that there was a dearth of pragmatic information contained in the textbooks and the variety of pragmatic information was limited. It is also in line with Wichien and Aksornjarung (2011) who found that pragmatic information in the textbooks was

The Pragmatics of Greetings Reflected in the Textbooks for Teaching English 6 as a Foreign Language in Indonesia 
inadequate as a source to gain pragmatic competence for EFL students.

\section{Conclusions}

This paper has indicated that textbooks do not always constitute accurate source of pragmatic information. It is also argued for the need to provide realistic models that are necessarily accompanied by adequate explanation of rules of use in order to facilitate learners' development of pragmatic competence in the TL. Another argument that the present study put forward is the new development in the role of English has urged teachers and textbook writers to reconsider the types of instructional materials that can most effectively prepare learners for communication in a wider and more diverse world. Finally, ESL/EFL instructional materials should also enrich learners' knowledge of their own language and culture and empower them to use English to express their unique identity as someone who know and can employ more than one language and culture (McKay, 2002 in LoCastro, 2008). A learning and teaching process that respect others languages and cultures can develop mutual understanding and appreciation among nations.

\section{References}

Aksoyalp, Y. \& Toprak, T. E. 2014. Incorporating Pragmatic in English Language Teachiing: To What Extent Do EFL Course Books Address Speech Acts? International Journal of Applied Linguistics \& English Literature. Vo. 4, No. 2. 125-133.

Alemi, M., Bemani, M. \& Roodi, F. Pragmatic Investigation in Three Global English Textbooks. The Internet Journal Language, Culture and Society. Vol. 36. 1-6.

Bardovi-Harlig, K. and Vellega, H.E. 2012. The effect of Instruction on Conventional Expressions in L2 Pragmatics. System (40) pp.70-89. (Retrieved from www.elsevier.com/ locate/system at April 30, 2013).

Brown, P. and Levinson, S. 1987. Politeness: Some Universals in Language Usage. Cambridge: Cambridge University Press.

Cox, C. 1999. Teaching Language Arts: A Student- and Response-Centered Classroom. USA: A Viacom Company.

Delen, B. and Tavil, Z. M. 2010. Evaluation of Four Coursebooks in Terms of Three Speech Acts: Requests, Refusals and Complaints. Procedia Social and Behavioral Sciences (9) pp. 692-697. (Retrieved from www.sciencedirect.com at April 30, 2013)

Diepenbroek, L. G. \& Derwing, T. M. 2013. To What Extent Do Popular ESL Textbooks Incorporate Oral Fluency and Pragmatic Development? TESL Canada Journal. Vol. 30, No. 7. 1-20.

Doddy, A., et al. 2008. Developing English Competencies for Senior High School (SMA/MA) Grade $X$ (BSE). Jakarta: Pusat Perbukuan Departemen Pendidikan Nasional.

Ebsworth, et al. 1996. Cross-Cultural Realization of Greetings in American

The Pragmatics of Greetings Reflected in the Textbooks for Teaching English $\quad 7$ as a Foreign Language in Indonesia 
English. Speech Acts Across Cultures by Gass, S.M. and Neu, J. New York: Mouton de Gruyter.

Ekin, M. T. Y. 2013. Do Current EFL Coursebooks work for the Development of L2 Pragmatic Competence? The case of Suggestion. Procedia-Social and Behavioral Sciences, Vol. 93, 1306-1310.

Ghobadi \& Fahim. 2009. The Effect of Explicit teaching of English "Thanking Formulas" on Iranian EFL Intermediate Level Students at English Language Institutes. System, Vol. 37, pp. 526-537.

Halenko, N. and Jones, C. 2011. Teaching Pragmatic Awareness of Spoken Requests to Chinese EAP Learners in the UK: Is Explicit Instruction Effective? System (39) 240-250. (Retrieved from www.elsevier.com/ locate/system at April 30, 2013).

Han, N. T. B. 2009. Contrastive Analysis: English and Vietnamese Greetings. University of Education.

Khatimah, Y. R., et. al. 2014. When English Rings a Bell. Jakarta: Kementrian Pendidikan dan Kebudayaan.

Kistanto, et. al. 2006. The Bridge English Competence for SMP Grade VII. Bogor: Yudhistira.

Kohandani, M., Farzaneh, N., \& Kazemi, M. 2014. A Critical Analysis of Speech Acts and Language Functions in Top Notch Series. Procedia-Social and Behavioral Sciences, Vol. 98, 1009-1015. (Retrieved from www.sciencedirect.com at October 20, 2014)

Koosha, B. \& Dastjerdi, H. V. 2011. Investigating Pragmatic Competence: The case of Requests in Interchange Series. Asian Social Science. Vol. 8, No. 1 , pp. 54-63.

Kumalarini, Th., at al. 2008. Bahasa Inggris untuk Sekolah Menengah Pertama Kelas VII (BSE). Jakarta: Pusat Perbukuan Departemen Pendidikan Nasional.

Li, W. 2009. Different Communication Rules between the English and Chineses Greetings. Asian Culture and History, Vol. 1, No. 2. 72-74.

LoCastro, V. 2008. Pragmatics for Language Educators: A Sociolinguistic Perspective. London: Routledge Taylor and Francis Group.

Lukman, D., et. al. 2007. Practice Your English. Bandung: HUP.

Narita, R. 2011. The Effects of Pragmatic Consciousness-Raising Activity on the Development of Pragmatic Awareness and Use of Hearsay Evidential Markers for Learners of Japanese as a Foreign Language. Journal of Pragmatics (44) pp. 1-29. (Retrieved from www.elsevier.com/locate/pragma at April 30, 2013).

Nguyen, T.T.M., at al. 2012. The Relative Effect of Explicit and Implicit FormFocused Instruction on the Development of L2 Pragmatic Competence. Journal of Pragmatics (44) pp. 416-434. (Retrieved from www.elsevier.com/locate/pragma at April 30, 2013).

Nguyen, T.T.M. 2011. Learning to Communicate in a Globalized World: To What Extent Do School Textbooks facilitate the Development of Intercultural Pragmatic Competence. RELC Journal (42) pp. 17-30.

Peiying, J. 2007. Exploring Pragmatic Knowledge in College English

The Pragmatics of Greetings Reflected in the Textbooks for Teaching English 8 as a Foreign Language in Indonesia 
Textbooks. CELEA Journal Vol. 30 No. 5. Pp. 109-119.

Pablos-Ortega, C. 2011. The Pragmatics of Thanking Reflected in the Textbooks for teaching Spanish as a Foreign Language. Journal of Pragmatics, Vol. 43. 2411-2433.

Priyana, J., et al. 2008. Interlanguage: English for Senior High School Students $X$ (BSE). Jakarta: Pusat Perbukuan Departemen Pendidikan Nasional.

Priyana, J., et al. 2008. Scaffolding: English for Junior High School Students (BSE). Jakarta: Pusat Perbukuan Departemen Pendidikan Nasional.

Salmani-Nodoushan, M. A. 2007. Greeting Forms in English and Persian: A Socio-Pragmatic Perspective. Pakistan Journal of Social Sciences, Vol. 4, No. 3, pp. 355-362.

Sekyi-Baidoo \& Koranteng, L. A. 2008. General Greetings in the Ghanaian Sociolinguistic Context. The International Journal of Language Society and Culture. Issue 26, pp. 113-127.

Soozandehfar, S. M. A. \& Sahragard, R. 2011. A Textbook Evaluation of Speech Acts and Language Functions in Top-Notch Series. Theory and Practice in Language Studies. Vol.1, No. 12, 1831-1838.

Takimoto, 2008. Exploring the Effects of Input-based Treatment and Test on the Development of Learners' Pragmatic Proficiency. Journal of Pragmatics (41) pp. 1029-1046. (Retrieved from www.elsevier.com/ locate/system at April 30, 2013).

Vaezi, R., Tabatabaei, S. \& Bakhtiarvand. 2014. A Comparative Study of Speech Acts in the Textbooks by Native and Non-Native Speakers: A Pragmatic Analysis of New Interchange Series vs. Locally-Made EFL Textbooks. Theory and Practice in Language Studies . Vol. 4, No. 1, pp. 167-180.

Wardiman, A., at al. 2008. English in Focus for Grade VII Junior High School (BSE). Jakarta: Pusat Perbukuan Departemen Pendidikan Nasional.

Wichien, S. and Aksornjarung, P. 2011. Pragmatic Features in English Course Materials Used at a Thai University. The $3^{\text {rd }}$ International Conference on Humanities and Social Sciences. Proceeding.

Zaida, N. 2013. Bright: An English Course for Junior High School Students. Jakarta: Penerbit Erlangga. 
Ahmad Dahlan Journal of English Studies (ADJES)

Vol. 3, Issue 2, September 2016

Appendix 1. Textbooks Analyzed in the Study

\begin{tabular}{|r|l|r|r|r|c|}
\hline No & \multicolumn{1}{|c|}{ Title } & Grade & Pubisher & Year & Code \\
\hline 1 & Scaffolding & VII & Kemendikbud & 2006 & Scf \\
\hline 2 & $\begin{array}{l}\text { Bahasa Inggris Sekolah Meneng } \\
\text { Pertama }\end{array}$ & VII & Kemendikbud & 2006 & BISMP \\
\hline 3 & English in Focus & VII & Kemendikbud & 2006 & EF \\
\hline 4 & The Bridge English Competence & VII & Yudhistira & 2006 & TBEC \\
\hline 5 & Practice Your English & VII & HUP & 2007 & PYE \\
\hline 6 & When English Rings a Bell & VII & Kemendikbud & 2014 & WERB \\
\hline 7 & Bright & VII & Erlangga & 2013 & Bri \\
\hline 8 & Developing English Competencies & $X$ & Kemendikbud & 2006 & DEC \\
\hline 9 & Interlanguage & $X$ & Kemendikbud & 2006 & Int \\
\hline
\end{tabular}

The Pragmatics of Greetings Reflected in the Textbooks for Teaching English 10 as a Foreign Language in Indonesia 